image, masthead touching masthead, and a sinall schooner under sail, some 8 or ro miles away, exhibited an inverted image of its topsails. In the direction of Saltburn a tug-boat (paddle steamer) steaming within perhaps 2 miles of the coast was quite normal in appearance. The smoke rising from it drifting eastwarl appeared normal for a short time, but suddenly expanded on rising to about ten times its thickness, and then tailed off again at its topmost eastward corner to the normal thickness. A large steamship lying about half-way across the bay showed no signs of being affected by the "mirage."

These phenomena disappeared in about 20 minutes, and were followed by a haze which obscured the distance.

The weather had been very hot and sultry all day, with about $70^{\circ}$ in the shade, and a gentle south-east by east breeze, and a perfectly clear sky.

Estimating the height of the Redcar houses at 50 feet and the distance at 7 miles, they would occupy $5^{\prime}$ of are; and taking the thickness of the air stratum producing the "mirage" at 35 ' of arc, the elongation of the buildings would be seven times their ordinary height.

Though I have been informed that "mirages" were visible on the previous hot days, the phenomenon is on the whole of rare occurrence here, and has never been witnessed by myself before.

Hartlepool, June I8.

Chas. O. Trechmans.

P.S.-My point of view would be about 20 feet above sea level.

\section{A Suggestion for Anthropologists.}

So far as the undersigned has seen, all reviewers of the "Précis d'Anthropologie," lately issued by Profs. Hovelacque and Hervé, of Paris, have noted with no little interest the attitude of the work towards the problem of the origin of man. Rejecting on the one hand the doctrine of the monogenesis of the human family in the way of a purely natural evolution out of lower forms of life, and on the other hand discrediting the poly. genesis of men by special creation in different centres of distribution, these eminent anthropologists present, as the probable truth: a compromise hypothesis, which they call transformisme polygénique. According to this view, men were evalved from the lower animals, but in more than one original centre, and from more than one original pair. A French reviewer has well intimated the significance of this new teaching by observing that it marks a distinct schism in the ranks of the Darwinistic anthropologists, and inaugurates debates and investigations from which most important new light may be expected.

In this connexion it has occurred to me that if I were an anthropologist, and especially one of Darwinian principles, I should be exceedingly eager to institute investigations looking to the establishment or overthrow of a still different conception of the matter-one not yet studied with anything like the thorough ness which it cleserves. I might call the hypothesis to which 1 allude the hypothesis of transformisme bigénique. Being neither its inventor nor a believer in it, I can the more freely call the attention of believers in transformism to its decided richness of promise. Indeed, if there is any middle ground of truth between the anthropolory of Darwin and the anthropology of Agassiz, it can nowhere so hopefully be sought as precisely here. The hypothesis to which I refer is that according to which the human family consists of the clescendants of two primitive human racesthe one white and originating at the North Pole, the other dark and originating at the South Pole.

The only work in which I have ever found this view suggested is one published in Sweden about the year 1842 , and two year later in an English translation, in London, under the following title: "The Theogony of the Kinclus; with their Systems of Philosophy and Cosmogony. An Essay, by Count M. Biornstjerna." I may be allowed to add that all I have published respecting the north polar origin of the race was already in its third edition before $\mathrm{I}$ had seen, or had any linowledge of, this work.

For the further satisfaction of those readers to whom the work may not be easily accessible, it may be stated that the iclea is by no means elaborated and formally mresented as a scientific solution of the problem of the origin of man. On the contrary, it is so transient and incidental a suggestion on the part of the Count that the substance of all he says is found in two sentences on page 177 of the English translation, as follows:- "As, according to the nature of the thing [i.e. owing to the secular cooling of the earth], both the polar regions mutst have been prepared equally early for the reception of mankind, it is possible that the appearance of man took place at the same time in both regions; perhaps the white race in the countries about the North Pole, and the black race in those about the South Pole. A number of difficult problems might hence be solved." How singular it would be if this passing remark of a Swedish Count, writing upon the mytholosy of the Hindus, and more than a generation ago, should prove to be the watchword of the most advanced school of scientific anthropologists at the opening of the twentieth century.

Bad Gastein, Austria, June 20.

WItLIAM F. WARREN.

\section{Snow in Central Germany.}

IN a note in NATURE of May I 2, p. 42, it was stated that the quantity of snow which feil in Central Germany from December is to 23 , between $50^{\circ}$ and $52^{\circ} \cdot 5 \mathrm{~N}$. latitude, and between $7^{\circ}$ and $18^{\circ} \mathrm{E}$. longitude, weighed no less than $10,000,000$ tons. I think there is a mistake in the calculation. Supposing that the snow was equivalent only to a stratum of water of 5 centimetres in height, its weight would be not $10,000,000$, but Io, 000, 000, 000 tons. Berlin, June $2 \mathrm{I}$.

OTTO KNOPF.

\section{Meteor.}

AT about 7.45 p.m. on June 19 a brilliant meteor was seen in broad daylight from this place. At a rough estimate it followed the meridian of Antares for about $30^{\circ}$, and disappeared near the meridian of that star.

Chithurst, Petersfield.

\section{Medicine in McGill University.}

IN a criticism of my "Outlines of Lectures on Physiology" which appeared in NATURE for May 12, you say :- "Pathology, or the application of physiology to disease, is hardly touched upon in this book. It is a most unfortunate omission unless both pathology and therapeutics are laught more systemalically than with us." About three years ago "Institutes of Medicine" (then including physiology proper, histology, and pathology) was divided, and now these departments are each taught separately, and each is provided with its own laboratory. A systematic course of lectures and demonstrations in pathology is given, with instruction and practice in making autopsies (after Virchow). Therapentics is taught from the physiological point of view, and also has its own laboratory. So that it only becomes necessary to make such reference to pathology, \&c., in the lectures on physiology as suffices to indicate that the subject does bear on the study of disease, and thus interest the student in it from its bearing on his life-work.

It may be interesting to English readers to learn that very recently two of Montreal's citizens have given one million dollars to erect and endow a "Royal Victoria Hospital " in commemoration of the Queen's Jubilee. This hospital is to be located close to McGill University.

I make these statements simply in justice to the Medical Faculty.

Phy:iological Laboratory, McGill University, Montreal, May 28.

\section{The University of Tokio.}

IN vol. xxxv. of NATURE, p. 40I, it was stated that the recent amalgamation of the Engineering College and the Unive:sity of Tokio occasioned the "total elimination of Europeans from the teaching staff, their place being taken by Japanese." Justice to the new University requires the correction of this statement, which is not only misleading, but erroneous. It is true that two well-known foreign Professors vacated their posts-one immediately after the amalgamation, and the other within six months thereafter. Their place, how ever (for they taught the same subject), is soon to be filled by an engineer who is expected shortly from England. But giving full allowance to this temporary vacancy, any person who will take the trouble to compare the number of foreign Professors in the two establishments before the incorporation with the number 